Fourth International Conference on Sustainable Construction Materials and Technologies http://www.claisse.info/Proceedings.htm

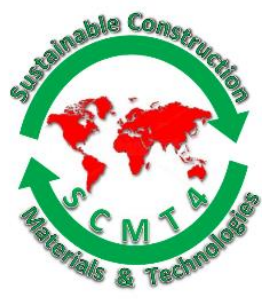

SCMT4

Las Vegas, USA, August 7-11, 2016

\title{
Oxyfuel Combustion Residues as Supplementary Cementitious Materials for the Production of Blended Portland Cements
}

\author{
A. Telesca*1a, M. Marroccoli ${ }^{1 b}$, N. Ibris ${ }^{1 c}$, F. Montagnaro² ${ }^{2}$ C. Lupiáñez ${ }^{3 a}$, \\ L. I. Díez ${ }^{3 b}$ and L. M. Romeo ${ }^{3 c}$ \\ ${ }^{1}$ School of Engineering, Università degli Studi della Basilicata, ITALY. \\ ${ }^{1 a}$ Email: <antonio.telesca@unibas.it>, ${ }^{1 b}$ Email: <milena.marroccoli@unibas.it>, \\ IcEmail: <neluta.ibris@unibas.it>. \\ ${ }^{2}$ Department of Chemical Sciences, Università degli Studi di Napoli Federico II, ITALY. \\ Email: 〈fabio.montagnaro@unina.it>. \\ ${ }^{3}$ CIRCE, Centro de Investigación de Recursos y Consumos Energéticos, Universidad de Zaragoza, \\ SPAIN. \\ ${ }^{3 a}$ Email: <carlos.lupianez@unizar.es>, ${ }^{3 b}$ Email $:<l u i s i g @ u n i z a r . e s>,{ }^{3 c}$ Email: <luismi@unizar.es>.
}

\begin{abstract}
Oxyfuel combustion represents one of the most interesting processes aimed at $\mathrm{CO}_{2}$ capture and storage to mitigate greenhouse effects ascribable to the process industry. In a different technical area, searching for new processes aimed at producing low- $\mathrm{CO}_{2}$ cements has comparable relevance, due to the huge generation of greenhouse gases related to cement production. This paper proposes an integration of these two aspects, with an approach new in the pertinent literature. The possibility of reusing ashes, issued by a pilot plant fluidized bed oxyfuel combustion process, as a source of material in the production of low- $\mathrm{CO}_{2}$ cements is investigated. Ashes were tested as substitutes for natural pozzolan in blended cements. They were mixed with an industrial Portland clinker and natural gypsum in order to evaluate their hydraulic behavior at different curing temperatures $\left(20-40^{\circ} \mathrm{C}\right)$ and times (2-28 days). Pozzolanicity tests together with differential thermal-thermogravimetric and X-ray diffraction analyses were employed to explore the hydration behavior of oxyfuel ashes-based blended cements.
\end{abstract}

\section{INTRODUCTION}

Global warming $(\mathrm{GW})$ is undoubtedly the main environmental and economic menace in our time, thus becoming a focus for the international community [Benhelal et al. 2013]. It is caused by the emissions of greenhouse gases (GHG) which are mainly released by the burning of fossil fuels, land clearing, agriculture and other human activities. The increase of the Earth's atmosphere as well as its oceans average temperature, the melting of permanent snow and polar ice caps together with the rise of the sea level represent unequivocal signs of GW [Zhang et al. 2012]. If not properly controlled and mitigated, these changes are predicted to determine catastrophic events. Among all GHG, carbon dioxide is the most important and abundant gas giving the largest contribution to GW phenomenon [IPCC 2007]. Since the industrial revolution, the concentration of $\mathrm{CO}_{2}$ in the Earth's atmosphere has increased tremendously, 
rising from $280 \mathrm{ppm}$ to more than $400 \mathrm{ppm}$ [Mauna Lao Observatory 2014]. In 2013 the global $\mathrm{CO}_{2}$ emissions were 35.3 billion tonnes, representing an increase of $2.0 \%$ with regard to the previous year [Olivier et al. 2014]. Almost $61 \%$ of global $\mathrm{CO}_{2}$ emissions is caused by industrial activities (electricity, heat generation and other industries) [IEA 2010; Walsh and Thornley 2012]. Therefore, searching for promising approaches to mitigate $\mathrm{CO}_{2}$ emission represents the priority of studies aimed at lowering the threat of climate change. A developing technology having the potential to almost completely eliminate $\mathrm{CO}_{2}$ emission from power plants and other industries (including cement factories) is 'carbon capture and storage [sequestration]' (CCS) [Herzog et al. 2000; Herzog 2001; IEA 2004; IPCC 2005; Leung et al. 2014]. CCS refers to a collection of technologies developed to capture the $\mathrm{CO}_{2}$ produced by combustion and to subsequently compress and inject it into geological strata [Blamey et al. 2010; Boot-Handford et al. 2014]. Among the different CCS processes, oxyfuel combustion (OFC) is of great interest due to its conceptual simplicity [Díez et al. 2015]. In OFC, nearly pure oxygen (instead of air) is used for combustion, thus lowering both the nitrogen amount and the NOx content in the exhaust gas [Buhre et al. 2005; Lupiáñez et al. 2013a, 2014] which, on the contrary, is in this case mainly composed by $\mathrm{CO}_{2}(80-$ $98 \%$ depending on the fuel used [Zero 2013]), ready for further processing and final storage.

Cement manufacturing is one of the most raw materials- and energy-intensive industrial processes. Moreover, its contribution to global anthropogenic $\mathrm{CO}_{2}$ emission is estimated as high as $6 \%$ [Xu et al. 2015]: the generation of this important GHG is due to both limestone thermal decomposition and fossil fuel combustion [Gartner 2004]. Low- $\mathrm{CO}_{2}$ Portland cements, namely hydraulic binders whose production process is associated with a reduced $\mathrm{CO}_{2}$ generation, can be obtained following two different approaches [Telesca et al. 2016]: 1) the use of a non-carbonated $\mathrm{CaO}$ source instead of limestone as a constituent of the Portland clinker-generating raw mix [Bernardo et al. 2007; Telesca et al. 2014, 2015; Perejón et al. $2016]$; 2) the increased production of blended cements, obtained by mixing Portland clinker with significant amounts of supplementary cementitious materials (e.g. natural pozzolans, coal fly-ashes, blastfurnace slags) [Mehta and Folliard 1995; Bilodeau and Malhotra 2000].

As matter of fact, the possibility of reusing ashes issued by an OFC process aimed at mitigating $\mathrm{CO}_{2}$ emissions as a source of material in the production of low- $\mathrm{CO}_{2}$ cements appears surely new in the literature scenario and worthy of investigation. So, in this paper residues generated during an OFC process, carried out in a fluidized bed (FB) reactor, were tested as substitutes for natural pozzolan in blended cements, thus allowing an integration of two very different processes but aimed at the same objective. OFC residues were mixed with an industrial Portland clinker and natural gypsum in order to evaluate their hydraulic behavior. Another mix, based on natural pozzolan, Portland clinker and natural gypsum was investigated as a reference term. Fratini pozzolanicity tests together with differential thermal-thermogravimetric (DTA-TG) and X-ray diffraction (XRD) analyses were employed to explore the hydration behavior of OFC ashes-based blended cements.

\section{EXPERIMENTAL INVESTIGATION}

Materials and pilot plant. Ordinary Portland clinker, natural gypsum and pozzolan, utilized for the pozzolanicity and hydration tests (mentioned below) were supplied by a local cement factory.

The OFC residues were generated in a $95 \mathrm{kWth}$ oxyfuel FB pilot plant (schematically represented in Figure 1) installed at CIRCE, Spain. This facility consists of a bubbling FB reactor $(2.5 \mathrm{~m}$ high with an inner diameter of $21 \mathrm{~cm}$ ) equipped with two different apparatuses for fly ash removal (baffle chamber $\mathrm{F}$ and cyclone $\mathrm{C}$, in the order). The FB combustor, cooled by means of a water jacket placed at the bottom of the reactor and four water-cooled probes uniformly distributed, was charged with a bed inventory of 5 $\mathrm{kg}$ silica sand, fluidized at $0.8 \mathrm{~m} \mathrm{~s}^{-1}$ with a $70 \% \mathrm{CO}_{2}-30 \% \mathrm{O}_{2}$ mixture and heated up to $850^{\circ} \mathrm{C}$. Two different types of coal (anthracite A and lignite L) were alternatively mixed with corn stover biomass (B) in a 80:20 energy ratio. The bed solids were fed to the reactor via endless screw connected to the lower part of the dense bed. Together with coal and biomass, Granicarb limestone was injected into the reactor 
to capture $\mathrm{SO}_{2}$ generated during combustion through in-situ desulfurization $(\mathrm{Ca}$ (in the sorbent): $\mathrm{S}$ (in the fuel) inlet ratio 2.5). The fly ashes retained through $\mathrm{F}$ and $\mathrm{C}$ are collected in two different deposits and extracted after the experiments. Bottom ash is taken from the lower part of the combustor (R). Full details on the plant can be retrieved elsewhere [Romeo et al. 2011; Lupiáñez et al. 2013b]. During the FB combustion tests six different residues were generated. AFFA, ACFA, ARBA (anthracite baffle chamber fly ash, anthracite cyclone fly ash and anthracite bottom ash, respectively) were residues obtained burning anthracite mixed with B. Similarly, when lignite was used instead of anthracite, the residues termed LFFA, LCFA and LRBA were obtained.

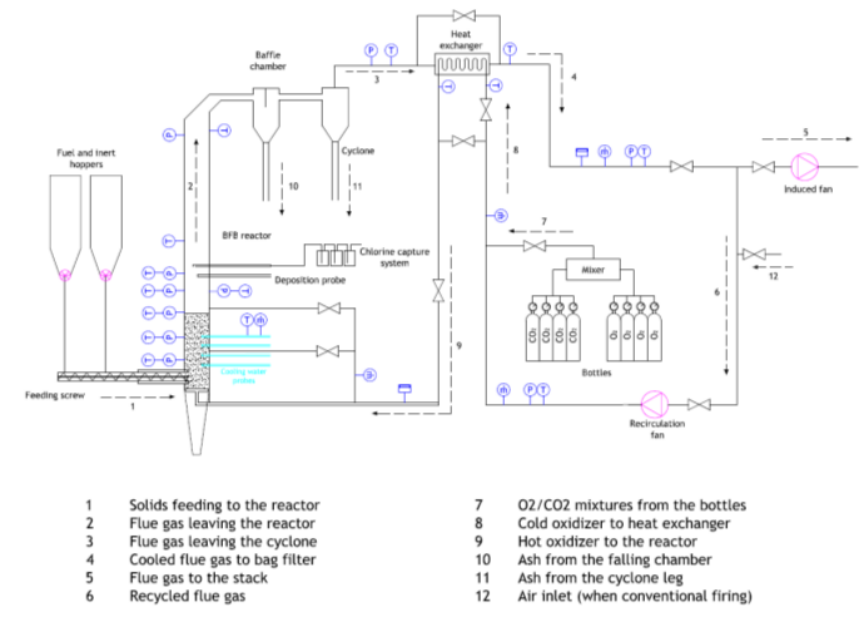

\section{Figure 1. Oxyfuel fluidized bed pilot plant installed at CIRCE, Spain}

The chemical composition of OFC residues was determined by X-ray fluorescence analysis (Bruker Explorer S4 apparatus) and is indicated in Table 1 together with the loss on ignition (1.o.i.) values. From Table 1 it can be argued that all the samples can be considered as F-type ashes inasmuch as their silicoaluminous fraction prevails over the calcic fraction and the l.o.i. at $950^{\circ} \mathrm{C}$ is mainly related to unburnt carbon, being not very different from the 1.o.i. at $550^{\circ} \mathrm{C}$ (actually, the difference in 1.o.i. between $550^{\circ} \mathrm{C}$ and $950^{\circ} \mathrm{C}$ should be ascribed to the $\mathrm{CaCO}_{3}$ content, originally derived from the raw limestone used as desulfurization sorbent).

Table 1. Chemical composition of OFC residues, mass \%

\begin{tabular}{|c|c|c|c|c|c|c|}
\hline & AFFA & ACFA & ARBA & LFFA & LCFA & LRBA \\
\hline $\mathrm{CaO}$ & 8.40 & 12.20 & 9.04 & 9.43 & 10.82 & 13.27 \\
\hline $\mathrm{SiO}_{2}$ & 25.66 & 26.97 & 71.36 & 36.75 & 26.46 & 56.75 \\
\hline $\mathrm{Al}_{2} \mathrm{O}_{3}$ & 8.73 & 12.82 & 8.25 & 13.48 & 13.76 & 10.65 \\
\hline $\mathrm{Fe}_{2} \mathrm{O}_{3}$ & 3.08 & 5.75 & 2.16 & 19.71 & 20.31 & 5.51 \\
\hline $\mathrm{K}_{2} \mathrm{O}$ & 2.57 & 2.95 & 2.11 & 1.31 & 1.57 & 1.30 \\
\hline $\mathrm{MgO}$ & 0.88 & 2.03 & 0.33 & 0.94 & 1.50 & 0.30 \\
\hline $\mathrm{MnO}$ & 0.02 & 0.03 & 0.01 & 0.03 & 0.04 & 0.01 \\
\hline $\mathrm{Na}_{2} \mathrm{O}$ & 0.37 & 0.77 & 0.14 & 0.07 & 0.10 & 0.03 \\
\hline $\mathrm{P}_{2} \mathrm{O}_{5}$ & 0.42 & 0.87 & 0.04 & 0.24 & 0.42 & 0.06 \\
\hline $\mathrm{SO}_{3}$ & 1.09 & 1.85 & 1.02 & 3.53 & 4.15 & 3.96 \\
\hline $\mathrm{TiO}_{2}$ & 0.47 & 0.63 & 0.36 & 0.47 & 0.58 & 0.30 \\
\hline $1.0 . i^{\#}$ & 41.60 & 27.90 & - & 9.80 & 13.50 & - \\
\hline 1.o.i. & 47.70 & 31.20 & 3.30 & 11.60 & 17.50 & 5.60 \\
\hline Total & 99.39 & 98.07 & 98.12 & 97.56 & 97.21 & 97.74 \\
\hline \#loss on ignition at $550^{\circ} \mathrm{C} \cdot *$ *oss on ignition at $950^{\circ} \mathrm{C}$ & & & \\
\hline
\end{tabular}


In particular, AFFA, ACFA, LFFA and LCFA residues displayed a l.o.i. larger than that allowed by the European Standard related to the use of fly ash in blended cements (EN 197-1). On the contrary, the two bottom ashes samples (ARBA and LRBA) are characterized by both significant amounts of the silicoaluminous fraction (about $80 \%$ and $67 \%$, respectively) and correspondingly low 1.o.i. values (3.3\% and $5.6 \%$, respectively), thus fulfilling the minimum technical requirements prescribed by the EN 197-1. The very limited carbon content for bottom ashes is related to their longer mean residence times into the OFC FB plant, ending up into larger burn-off degrees.

Mixtures formulation, pozzolanicity and hydration tests. On the basis of the above mentioned considerations, only bottom ashes were investigated in this experimental work. ARBA and LRBA ashes (obtained by burning anthracite and lignite, respectively) were mixed with Portland clinker and natural gypsum in order to evaluate their pozzolanicity as well as hydration behavior. Another mix based on natural pozzolan, Portland clinker and natural gypsum was investigated as a reference term. In order to evaluate the reactivity of the two bottom ashes, a pozzolanicity test was carried out. This test must be performed on blended pozzolanic cements and gives an indication of the suitability of a pozzolanic addition to be used in mixture with Portland clinker and natural gypsum. The pozzolanicity is assessed by comparing the concentration of calcium ion expressed as calcium oxide present in the aqueous solution (in contact with the hydrated cement for 8 days at $40^{\circ} \mathrm{C}$ ) with the quantity of calcium ion capable of saturating a solution of the same alkalinity. The pozzolanic cement (and the related pozzolanic addition) is considered to satisfy the test if the concentration of calcium ion in the solution is lower than the saturation concentration (zone "1" in Figure 2).

Two pozzolanic cements (C_ARBA and C_LRBA) were prepared for the pozzolanicity test. They were respectively composed by $61 \%$ and $55 \%$ Portland clinker, $34 \%$ and $40 \%$ pozzolanic addition (ARBA and LRBA) and 5\% gypsum, ground in a laboratory mill to a Blaine fineness equal to $380 \mathrm{~m}^{2} \mathrm{~kg}^{-1}$. A cement (C_R) having the composition commonly employed for industrial pozzolanic cements $(55 \%$ Portland clinker, $40 \%$ natural pozzolan and 5\% gypsum) and ground at the almost the same Blaine value was employed as a reference term. Twenty grams of each cement were added to $100 \mathrm{~mL}$ of water and, at the end of the accelerated curing, $\mathrm{OH}^{-}$and $\mathrm{Ca}^{++}$concentrations were measured according to EN 196-5.

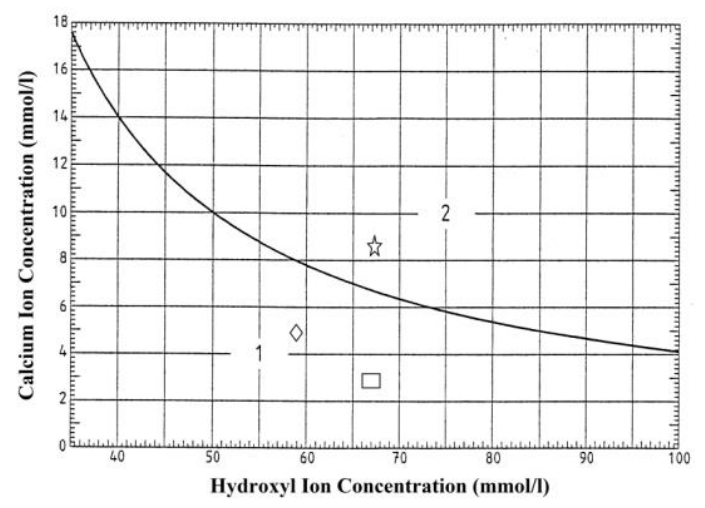

\section{Figure 2. Saturation curve at $40^{\circ} \mathrm{C}$ together with the indication of the pozzolanicity test results for C_R (rectangle), C_ARBA (star) and C_LRBA (rhombus) cements. Zone " 1 " represents the domain in which the test "passes", zone " 2 " where it "fails"}

The three cements were also submitted to hydration tests in order to evaluate the reactivity of the employed residues, namely their ability to react with calcium hydroxide (produced during the Portland clinker hydration) for generating calcium silicate hydrates and calcium aluminate hydrate, namely the typical ordinary Portland cement (OPC) hydration products. Hydration of the cement pastes (water/cement mass ratio equal to 0.5 ) was carried out in a thermostatic bath, for various curing times (2- 
28 days) and temperatures $\left(20-40^{\circ} \mathrm{C}\right)$. At the end of each aging period, the specimens were (i) pulverized, (ii) treated with acetone (to stop hydration) and diethyl ether (to remove water), (iii) stored in a desiccator over silica gel-soda lime (to ensure protection against $\mathrm{H}_{2} \mathrm{O}$ and $\mathrm{CO}_{2}$ ) and (iv) submitted to DTA-TG and XRD analyses. Simultaneous DTA-TG analysis was performed with a NETZSCH-Tasc 414/3 apparatus, operating between room temperature and $1000^{\circ} \mathrm{C}$, heating rate $10^{\circ} \mathrm{C} \mathrm{min}{ }^{-1}$. TG analysis was also used for quantitative purposes, to determine the calcium hydroxide concentration in the hydrated systems. XRD analysis was employed for the mineralogical determination of cements hydration products; it was carried out by means of a BRUKER D2 Phaser diffractometer $\left(\mathrm{Cu} \mathrm{k} \alpha\right.$ radiation, $0.02^{\circ} 2 \theta \mathrm{s}^{-1}$ scanning rate), operating between $5^{\circ}$ and $60^{\circ} 2 \theta$.

\section{RESULTS AND DISCUSSION}

Only the lignite-derived bottom ash (LRBA) residue showed a reactivity similar to that of natural pozzolan; as a matter of fact, both LRBA and natural pozzolan satisfied the pozzolanicity test inasmuch as the representative points of the related cements (rhombus and rectangle, respectively) are located below the saturation curve (zone "1" in Figure 2). On the contrary, the representative point of C_ARBA cement is located above the saturation curve (star in zone "2"), thus highlighting its worse pozzolanicity, most probably due to the low amorphous $\mathrm{SiO}_{2}$ and $\mathrm{Al}_{2} \mathrm{O}_{3}$ content. This result was also confirmed by a further pozzolanicity test carried out on a sample hydrated for 15 days at $40^{\circ} \mathrm{C}$.

Figures 3-5 illustrate the DTA-TG thermograms for C_R, C_ARBA and C_LRBA cements cured for selected temperatures and times.
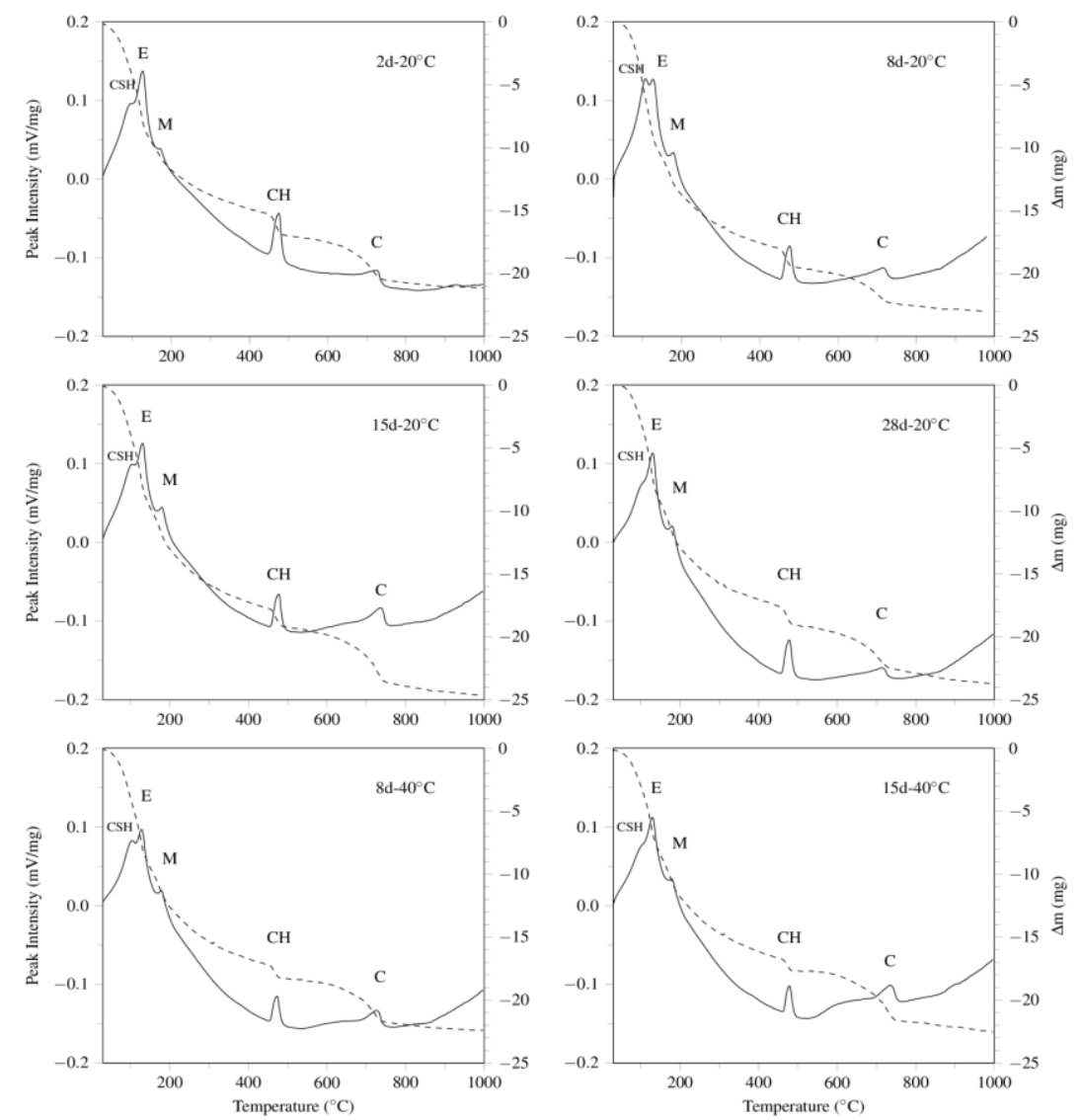

Figure 3. DTA-TG thermograms for the reference C_R cement hydrated at $20^{\circ} \mathrm{C}$ for 2,8 , 15 and 28 days and at $40^{\circ} \mathrm{C}$ for 8 and 15 days $(\mathrm{CSH}=$ calcium silicate hydrate; $\mathrm{E}=\mathrm{C}$ ettringite; $\mathrm{M}=$ monosulfate; $\mathbf{C H}=$ calcium hydroxide; $\mathrm{C}=$ calcium carbonate). $\mathrm{DTA}=$ continuous curve, left-hand $\mathbf{y}$-axis; $\mathbf{T G}=$ dashed curve, right-hand $\mathbf{y}$-axis 
With DTA-TG temperature increasing, five endothermal effects were observed and attributed [Taylor 1997] to the following compounds, in the order: calcium silicate hydrate, ettringite, monosulfate, calcium hydroxide and calcium carbonate through the following dehydration endothermal peaks: $98^{\circ} \pm 6^{\circ} \mathrm{C}$, $133^{\circ} \pm 3^{\circ} \mathrm{C}, 178^{\circ} \pm 3^{\circ} \mathrm{C}, 478^{\circ} \pm 5^{\circ} \mathrm{C}, 728^{\circ} \pm 27^{\circ} \mathrm{C}$, respectively.
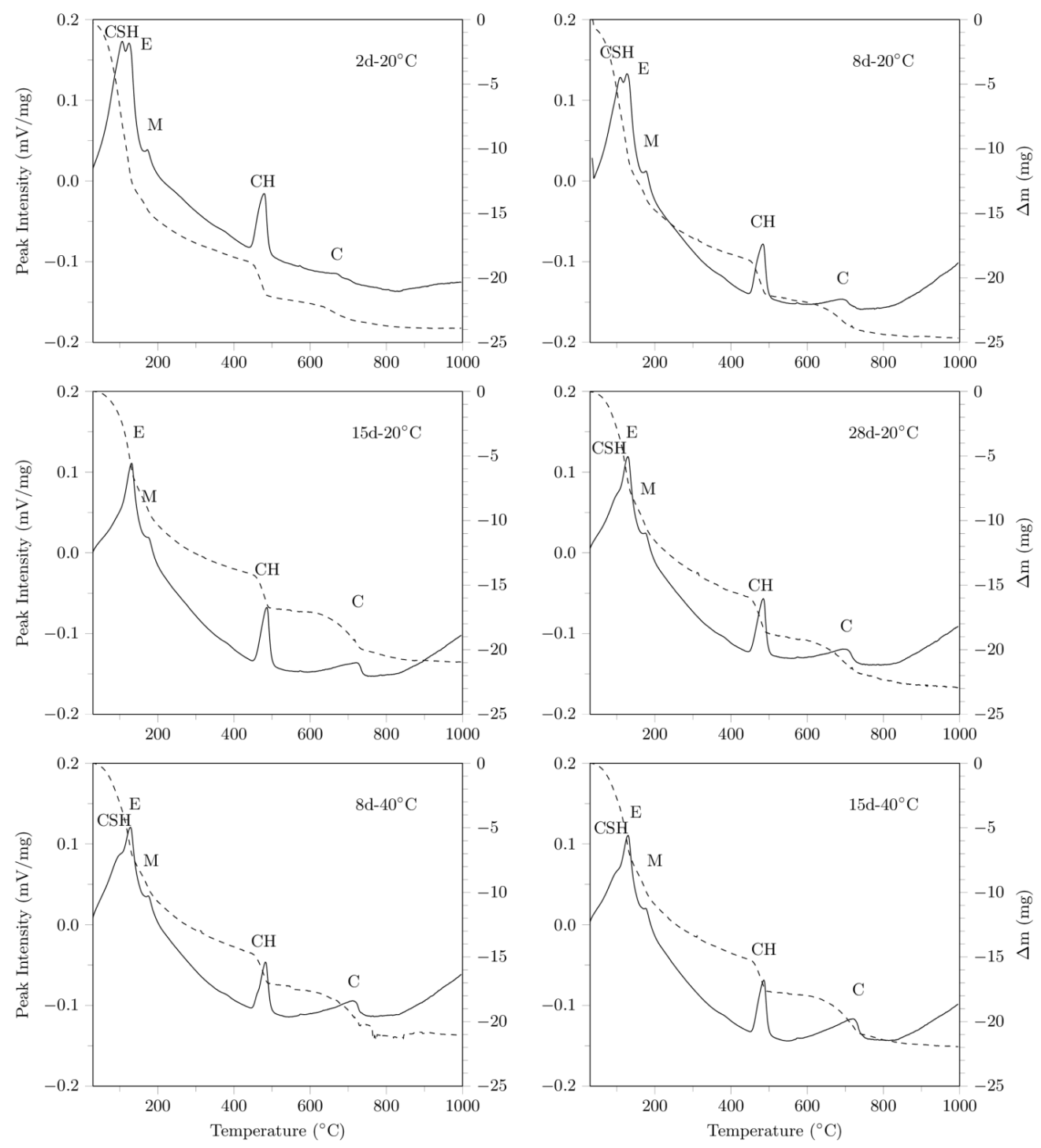

Figure 4. DTA-TG thermograms for C_ARBA cement hydrated at $20^{\circ} \mathrm{C}$ for $2,8,15$ and 28 days and at $40^{\circ} \mathrm{C}$ for 8 and 15 days (same legend as in Figure 3 )

The thermograms of all the cement pastes based on OFC ashes showed a strong qualitative similarity when compared to the reference cement. This result highlights the OFC bottom ashes feature of acting as reactive cementitious materials. Among the thermograms, the main difference concerned the presence of monosulfate in C_R and C_ARBA (and not in C_LRBA). Monosulfate formed in C_R and C_ARBA already at early $(24 \mathrm{~h})$ curing ages. The absence of this secondary hydration product when dealing with C_LRBA could be ascribed to its larger sulfate content (see Table 1), that could make ettringite more stable and then less prone to decompose toward monosulfate. A particular feature of C_LRBA was to exhibit two different endothermal peaks related to the decomposition of calcium carbonate. 

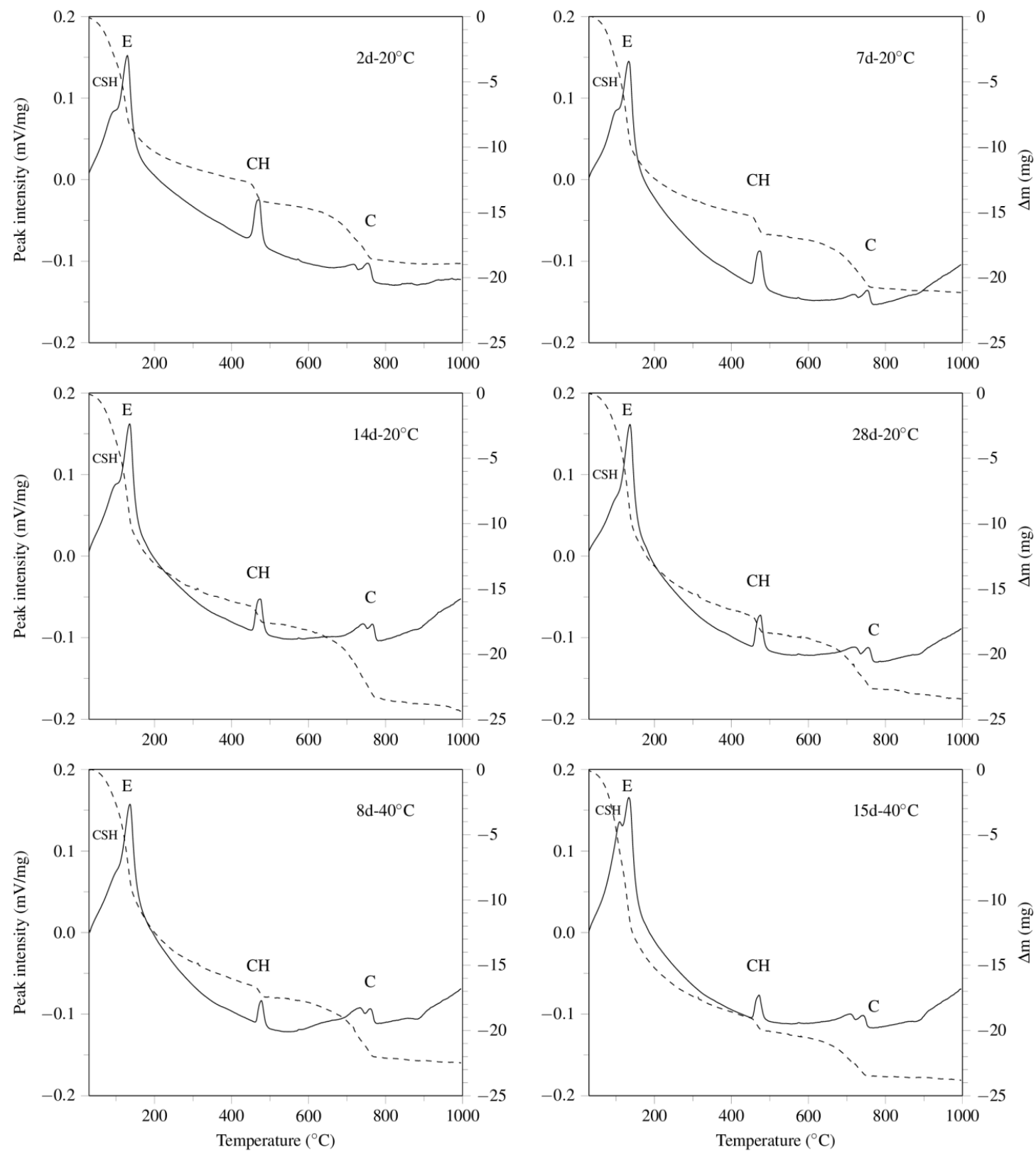

Figure 5. DTA-TG thermograms for C_LRBA cement hydrated at $20^{\circ} \mathrm{C}$ for $2,7,14$ and 28 days and at $40^{\circ} \mathrm{C}$ for 8 and 15 days (same legend as in Figure 3)

Calcium hydroxide concentration vs. curing time $\left(20^{\circ} \mathrm{C}\right)$ for the three hydrating systems is reported in Figure 6. According to what previously observed, a low $\mathrm{Ca}(\mathrm{OH})_{2}$ concentration is an index of a good system hydration reactivity toward calcium silicate hydrates. Therefore, when compared with the reactivity of the anthracite-derived ash, that of both natural pozzolana and lignite-derived ash appears more satisfying, as arising from both the lower absolute $\mathrm{Ca}(\mathrm{OH})_{2}$ concentration values and the decrease of the $\mathrm{Ca}(\mathrm{OH})_{2}$ concentration value with the increase in curing time (C_R and $\mathrm{C}_{-} L R B A$ vs. C_ARBA case). Particularly interesting is the similarity between the behaviour of the reference cement and that of C_LRBA cement. These results are in agreement with the pozzolanicity test, and again qualify the lignitederived OFC ash as an interesting material for cementitious applications. 


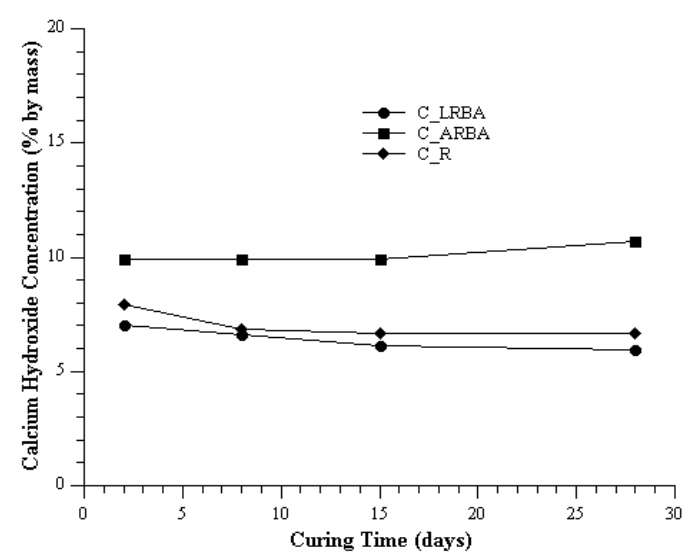

Figure 6. Calcium hydroxide concentration for $C_{-} R, C_{-} A R B A$ and $C_{-} L R B A$ cements $v$ s. curing time at $20^{\circ} \mathrm{C}$

XRD data on hydrated systems agree with DTA results in highlighting the similarity between the reference cement and those OFC ashes-based. As an example, the diffractograms for C_R and C_LRBA (different curing times, $20^{\circ} \mathrm{C}$ ) are illustrated in Figure 7. Peaks for ettringite and portlandite as hydration products, and quartz, belite, calcite and anhydrite as raw cement materials, were observed. In particular, due to the pozzolanic activity of both natural pozzolan and lignite-derived oxyfuel residue, the decrease of the portlandite peaks intensity is easily observed in Figure 7 with the increase of curing time (see for example peaks around $18^{\circ} 2 \theta$ ), in agreement with discussion of the results of Figure 6.
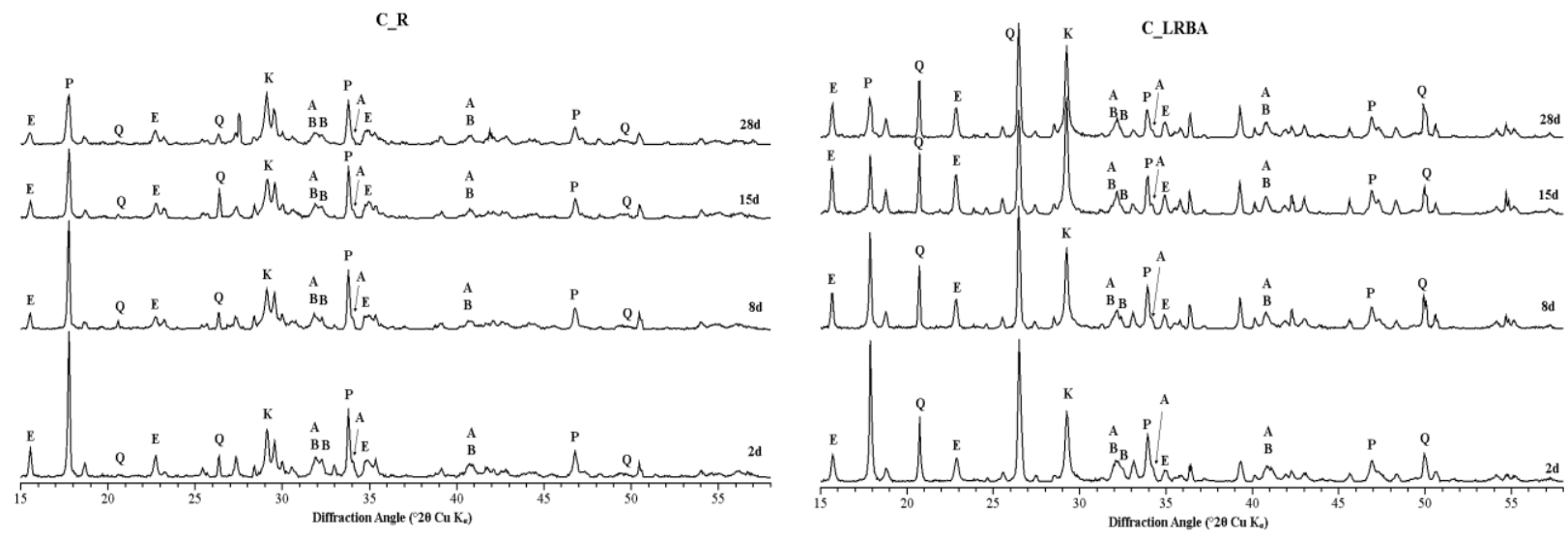

Figure 7. XRD patterns for $C_{-}$R and C_LRBA cements hydrated at $20^{\circ} \mathrm{C}$ for $2,8,15$ and 28 days $(\mathrm{E}=$ =ettringite; $\mathrm{P}=$ portlandite; $\mathrm{Q}=\mathbf{q u a r t z} ; \mathrm{B}=\mathrm{belite} \mathbf{K}=$ calcite; $\mathrm{A}=$ =anhydrite)

\section{CONCLUSION}

The hydraulic behavior of two residues coming from a pilot-oxyfuel fluidized bed combustor (OFC residues) employed as substitutes for natural pozzolan in blended cements was investigated. OFC residues derived from a burning process of two different types of coal (anthracite and lignite) alternatively mixed with corn stover biomass in a 80:20 energy ratio. The preliminary results reported in this paper highlight that OFC residues contain silicoaluminous components potentially able to combine with calcium hydroxide generated during Portland clinker hydration. These by-products are very interesting since their utilization as secondary cementitious materials, in addition to the saving of raw materials, allows a clinker dilution which implies a decreased emission of $\mathrm{CO}_{2}$ and pollutants as well as an increased energy saving per unit mass of cement. It has been found that, despite the high silica content, lignite-biomass bottom ash 
satisfied the pozzolanicity test, at odds with what observed for anthracite-biomass bottom ash. Nevertheless, by following the hydration behavior through thermal, chemical and diffractometric analyses, similarities were shown by the two investigated (lignite ash- and anthracite ash-based) blended cements when compared to a reference commercial cement. Forthcoming activity is therefore going to investigate in more detail the process idea proposed in this preliminary paper. In fact, the possibility of integrating these two processes (oxyfuel combustion and production of low- $\mathrm{CO}_{2}$ cements), very different each other but both devoted to limit the emission of greenhouse gas, together with the reuse of industrial solid wastes, appears very interesting and poorly investigated in the related literature.

\section{REFERENCES}

Benhelal, E., Zahedi, G., Shamsaei, E., and Bahadori, A. (2013). "Global strategies and potentials to curb $\mathrm{CO}_{2}$ emissions in cement industry.” Journal of Cleaner Production, 51, 142-161.

Bernardo, G., Marroccoli, M., Nobili, M., Telesca, A., and Valenti, G.L. (2007). "The use of oil wellderived drilling waste and electric arc furnace slag as alternative raw materials in clinker production." Resources, Conservation and Recycling, 52, 95-102.

Bilodeau, A., and Malhotra, V.M. (2000). "High-volume fly ash system: concrete solution for sustainable development." ACI Materials Journal, 97, 41-47.

Blamey, J., Anthony, E.J., Wang, J., and Fennell, P.S. (2010). “The calcium looping cycle for large-scale $\mathrm{CO}_{2}$ capture." Progress in Energy and Combustion Science, 36, 260-279.

Boot-Handford, M.E., Abanades, J.C., Anthony, E.J., Blunt, M.J., Brandani, S., Mac Dowell, N., Fernández, J.R., Ferrari, M.C., Gross, R., Hallett, J.P., Haszeldine, R.S., Heptonstall, P., Lyngfelt, A., Makuch, Z., Mangano, E., Porter, R.T.J., Pourkashanian, M., Rochelle, G.T., Shah, N., Yao, J.G., and Fennell, P.S. (2014). "Carbon capture and storage update.” Energy \& Environmental Science, 7, 130189.

Buhre, B.J.P., Elliott, L.K., Sheng, C.D., Gupta, R.P., and Wall, T.F. (2005). "Oxy-fuel combustion technology for coal-fired power generation." Progress in Energy and Combustion Science, 31, 283 307.

Díez, L.I., Lupiáñez, C., Guedea, I., Bolea, I., and Romeo, L.M. (2015). “Anthracite oxy-combustion characteristics in a $90 \mathrm{~kW}_{\text {th }}$ fluidized bed reactor." Fuel Processing Technology, 139, 196-203.

Gartner, E. (2004). "Industrially interesting approaches to "low- $\mathrm{CO}_{2}$ " cements." Cement and Concrete Research, 34, 1489-1498.

Herzog, H., Eliasson, B., and Kaarstad, O. (2000). "Capturing greenhouse gases." Scientific American, $282,72-79$.

Herzog, H.J. (2001). "What future for carbon capture and sequestration?" Environmental Science \& Technology, 35, 148-153.

IEA (2004). "Prospects for $\mathrm{CO}_{2}$ capture and storage." OECD/IEA.

IEA (2010). " $\mathrm{CO}_{2}$ emissions from fuel combustion highlights." www.iea.org/co2highlights.

IPCC (2005). "IPCC special report on carbon dioxide capture and storage.” In: Metz B, Davidson O, de Connick HC, Loos M, Meyer LA, editors. IPCC: Geneva, Switzerland.

IPCC (2007). "Climate change 2007: synthesis report. Contribution of Working Groups I, II and III to the fourth assessment report of the intergovernmental panel on climate change." In: Pachauri KP, Reisinger A, editors. IPCC: Geneva, Switzerland.

Leung, D.Y.C., Caramanna, G., and Maroto-Valer, M.M. (2014). "An overview of current status of 
carbon dioxide capture and storage technologies." Renewable and Sustainable Energy Reviews, 39, 426-443.

Lupiáñez, C., Díez, L.I., and Romeo, L.M. (2013a). "NO emissions from anthracite oxy-firing in a fluidized-bed combustor: effect of the temperature, limestone, and $\mathrm{O}_{2}$." Energy \& Fuels, 27, 76197627.

Lupiáñez, C., Guedea, I., Bolea, I., Díez, L.I., and Romeo, L.M. (2013b). "Experimental study of $\mathrm{SO}_{2}$ and NOx emissions in fluidized bed oxy-fuel combustion." Fuel Processing Technology, 106, 587-594.

Lupiáñez, C., Díez, L.I., and Romeo, L.M. (2014). "Influence of gas-staging on pollutant emissions from fluidized bed oxy-firing." Chemical Engineering Journal, 256, 380-389.

Mauna Lao Observatory (2014). "Scripps $\mathrm{CO}_{2}$ Program.” www.co2now.org.

Mehta, P.K., and Folliard, K.J. (1995). "Rice husk ash - A unique supplementary cementing material: durability aspects." Proceedings of Fifth CANMET/ACI International Conference on Fly Ash, Silica Fume, Slag and Natural Pozzolans in Concrete, ACI SP-153, 531-541.

Olivier, J.G.J., Janssens-Maenhout, G., Muntean, M., and Peters, J.A.H.W. (2014). "Trend in global $\mathrm{CO}_{2}$ emissions: 2014 Report." PBL Netherlands Environmental Assessment Agency The Hague.

Perejón, A., Romeo, L.M., Lara, Y., Lisbona, P., Martínez, A., and Valverde, J.M. (2016). “The CalciumLooping technology for $\mathrm{CO}_{2}$ capture: On the important roles of energy integration and sorbent behavior." Applied Energy, 162, 787-807.

Romeo, L.M., Díez, L.I., Guedea, I., Bolea, I., Lupiáñez, C., González, A., Pallarés, J., and Teruel, E. (2011). "Design and operation assessment of an oxyfuel fluidized bed combustor." Experimental Thermal and Fluid Science, 35, 477-484.

Taylor, H.F.W. (1997). "Cement chemistry.” 2nd Ed., Academic Press.

Telesca, A., Calabrese, D., Marroccoli, M., Tomasulo, M., Valenti, G.L., Duelli (Varela), G., and Montagnaro, F. (2014). "Spent limestone sorbent from calcium looping cycle as a raw material for the cement industry." Fuel, 118, 202-205.

Telesca, A., Marroccoli, M., Tomasulo, M., Valenti, G.L., Dieter, H., and Montagnaro, F. (2015). "Calcium looping spent sorbent as a limestone replacement in the manufacture of Portland and calcium sulfoaluminate cements.” Environmental Science \& Technology, 49, 6865-6871.

Telesca, A., Marroccoli, M., Tomasulo, M., Valenti, G.L., Dieter, H., and Montagnaro, F. (2016). "Low$\mathrm{CO}_{2}$ cements from fluidized bed process wastes and other industrial by-products." Combustion Science and Technology, Accepted for publication.

Walsh, C., and Thornley, P. (2012). "Barriers to improving energy efficiency within the process industries with a focus on low grade heat utilization." Journal of Cleaner Production, 23, 138-146.

Xu, D., Cui, Y., Li, H., Yang, K., Xu, W., and Chen, Y. (2015). "On the future of Chinese cement industry." Cement and Concrete Research, 78, 2-13.

Zero, Zero Emissions Resource Organization (2013). www.zeroCO2.no.

Zhang, X.F., Zhang, S.Y., Hu, Z.Y., Yu, G., Pei, C.H., and Sa, R.N. (2012). "Identification of connection units with high GHG emissions for low-carbon product structure design." Journal of Cleaner Production, 27, 118-125. 